\title{
Effects of Indonesian marine sponges ethanol extracts on the lipid profile of hyperlipidemic rats
}

\author{
Wahyuni Wahyuni ${ }^{1}$, Adryan Fristiohady ${ }^{1}$, Muhammad Hajrul Malaka ${ }^{1}$, Fadhliyah Malik ${ }^{1}$, Muhammad Ilyas Yusuf ${ }^{1}$, \\ Mesi Leorita ${ }^{1}$, Baru Sadarun², Ahmad Saleh ${ }^{3}$, Wa Ode Sitti Musnina ${ }^{4}$, Carla W. Sabandar ${ }^{5}$, Idin Sahidin ${ }^{1 *}$ \\ ${ }^{1}$ Faculty of Pharmacy, Universitas Halu Oleo, Kendari, Indonesia. \\ ${ }^{2}$ Faculty of Fisheries and Marine Sciences, Universitas Halu Oleo, Kendari, Indonesia. \\ ${ }^{3}$ Department of Pharmacy, STIKES Mandala Waluya, Kendari, Indonesia. \\ ${ }^{4}$ Department of Pharmacy, Faculty of Mathematics and Natural Sciences, Universitas Tadulako, Palu, Indonesia. \\ ${ }^{5}$ Department of Pharmacy, Faculty of Science and Technology, Universitas Sembilanbelas November Kolaka, Indonesia.
}

\section{ARTICLE INFO \\ Received 05/04/2019 \\ Accepted 30/07/2019 \\ Available Online: 05/10/2019}

\section{Key words:}

Antihyperlipidemia, marine

sponge, Callyspongia sp.,

Melophlus sarasinorum,

Xestospongia sp.

\begin{abstract}
This study was aimed to investigate the effects of ethanol extracts of Indonesian marine sponges (Callyspongia sp., Melophlus sarasinorum, and Xestospongia sp.) on the lipid profile of hyperlipidemic rats. The antihyperlipidemic study of these sponges is firstly reported in this study. Experimental hyperlipidemic rats were induced by daily intake of propylthiouracil $(1.8 \mathrm{mg} / 200 \mathrm{~g} \mathrm{~b}$.wt and quail yolk $(10 \mathrm{ml} / \mathrm{kg})$ for the duration of 3 weeks. Hyperlipidemic rat groups were administered orally with three doses $(30,60$, and $120 \mathrm{mg} / \mathrm{kg})$ of the ethanol extracts for 1-week onward. Blood sample was then collected via intracardiac puncture and serum was biochemically analyzed. Ethanol extracts of Callyspongia sp., M. sarasinorum, and Xestospongia sp. at doses of 60 and $120 \mathrm{mg} / \mathrm{kg}$ exhibited a significant reduction of cholesterols, triglycerides, and low-density lipoprotein. These doses also significantly increased the highdensity lipoprotein level. Levels of atherogenic indices (Atherogenic Index, Atherogenic Index Plasma, Castelli's Risk Index-I, and Castelli's Risk Index-II) were also decreased by both doses with percentages protection ranging from $70.6 \%$ to $81.6 \%$. These results showed that ethanol extracts of Callyspongia sp., M. sarasinorum, and Xestospongia sp. exhibited a lipid-lowering activity in hyperlipidemic rats. Hence, these extracts could be used as sources of lead molecules in the development of natural lipid-lowering agents from marine species.
\end{abstract}

\section{INTRODUCTION}

Cardiovascular Disease (CVD) is one of the major causes of death in the global human population. In 2016, 17.9 million people died each year from CVD (WHO, 2017). The risk factors of CVD include hyperlipidemia, which is a condition with elevated levels of low-density lipoprotein (LDL), cholesterol, and triglycerides and with low levels of high-density lipoprotein (HDL) cholesterols. Medications such as statins can be used to lower the cholesterol levels in the blood (Clark et al., 2012). However, in Indonesia, native people preferably apply traditional medicines as an alternative than using chemical drugs to prevent

${ }^{*}$ Corresponding Author

Idin Sahidin, Faculty of Pharmacy, Universitas Halu Oleo, Kendari,

Indonesia.E-mail: sahidin02@uho.ac.id and reduce cholesterol levels in the blood. This behavior is also supported by the rich biodiversity of this nation (Dahuri, 2003)

Indonesia's vast marine biodiversity provides an opportunity for biota to be used as a new source for new medicines. One of the marine biotas that has bioactive compounds and has the potential as a medicinal ingredient is marine sponges. Sponges such as Callyspongia sp., Melophlus sarasinorum, and Xestospongia sp. can be studied for their activity for their lowering cholesterol level activity in the blood (Artanti et al., 2016; Dahuri, 2003). In previous studies, these sponges are reported to exhibit potential pharmacological activities, such as antibacterial, anticancer, antifungal, and many unknown benefits (Cita et al., 2017; Menggelea et al., 2015; Tapilatu, 2015). Compounds isolated from sponges are secondary metabolites containing steroids, alkaloids, flavonoids, terpenoids, saponins, and phenols (Hariani et al., 2014; Ivanchina et al., 2011; Menggelea et al., 2015). In 
addition, compounds isolated from sponges-associated fungi showed a lipid-lowering activity assayed using in vitro and in vivo models (Blunt and Munro, 2008). Thus, in this study, we aimed to determine the effectiveness of Callyspongia sp., M. sarasinorum, and Xestospongia sp. ethanol extracts as an antihyperlipidemic based on the lipid profile in male Wistar rats.

\section{MATERIALS AND METHODS}

\section{Sponges collection}

Sponge samples of Callyspongia sp. (1 kg), $M$. sarasinorum (1.8 kg), and Xestospongia sp. (1.2 kg) (Fig. 1) were collected by hand with SCUBA diving from the reef slope area of the Lapuko beach of Moramo district, Southeast Sulawesi, Indonesia, at a depth of $10 \mathrm{~m}$, in May 2015. The expert staff of the Faculty of Fisheries and Marine Science of Universitas Halu Oleo carefully handled the procedure of samples collection and specimen identification. The collected sponges were separately stored in their respective cool boxes and urgently brought back to the laboratory for analyses. Specimens of these sponges were deposited with voucher numbers of UHO-2015-01, UHO-201502, and UHO-2015-04, respectively.

\section{Extraction}

The dried sponge samples of Callyspongia sp. (0.98 $\mathrm{kg})$, M. sarasinorum (1 kg), and Xestospongia $\mathrm{sp}$. (1 kg) were macerated with ethanol $(96 \%)$ for three times each for 24 hours and filtered using Whatman filter papers. Their filtrates were concentrated under reduced pressure and yielded dried ethanol extracts. Each extract were labeled accordingly as EC (6 g) for Callyspongia sp., EM (10 g) for M. sarasinorum, and EX (8 g) for Xestospongia sp. All extracts were then stored in amber containers and kept in a refrigerator at $4^{\circ} \mathrm{C}$ until further use.

\section{Animals and ethics}

Male Wistar rats (100-200 g) used in this study were obtained from the veterinary clinic Drh. Rachmad Priyadi, Surabaya, Indonesia. The animals were adapted to the new environment for 1 week under standard environmental conditions, including ambient temperature of $25^{\circ} \mathrm{C}-27^{\circ} \mathrm{C}$ for $12 / 12$ hours light and dark cycle. They were fed with standard commercially rats diet. Either food or water was provided ad libitum throughout the period of the study. The body weights of rats were daily recorded and no significant change was observed when compared with those records from the beginning of the study. All experiments involving animals in this study were conducted in accordance with the Animal Ethics Committee of Halu Oleo University (approval number 11676/UN29.20/PPM/2017).

\section{Experimental design}

After 1 week of acclimatization, four animals were continuously maintained with standard rat diet and designated as the normal control group (Group I). Hyperlipidemia in 44 rats was induced by propylthiouracil (PTU) $(1.8 \mathrm{mg} / 200 \mathrm{~g}$ of body weight) and quail yolk (Qy) $(10 \mathrm{ml} / \mathrm{kg}$ of body weight). The induction was made two times a day for 3 weeks. In the morning, rats were given orally with quail yolk each $5 \mathrm{ml}$, while the combination of PTU $(1.8 / 200 \mathrm{~g}$ b.wt.) and quail yolk $(5 \mathrm{ml})$ was administered in the evening. At day 21 (3 weeks), hyperlipidemic rats were divided into designated groups (Groups II to XI) and treated accordingly for another 1 week.

Group I: $\quad$ Normal control (standard diet, no treatment)

Group II: High cholesterol control (PTU-quail yolk diet, no treatment)

Group III: $\quad$ Positive control (PTU-quail yolk diet, 0.18 $\mathrm{mg} / 200 \mathrm{~g}$ b.wt. simvastatin)

Group IV: $\quad$ PTU-Qy diet $+30 \mathrm{mg} / \mathrm{kg}$ of Callyspongia $\mathrm{sp}$. extract (EC30)

Group V: $\quad$ PTU-Qy diet $+60 \mathrm{mg} / \mathrm{kg}$ of Callyspongia $\mathrm{sp}$. extract (EC60)

Group VI: $\quad$ PTU-Qy diet $+120 \mathrm{mg} / \mathrm{kg}$ of Callyspongia $\mathrm{sp}$. extract (EC120)

Group VII: $\quad$ PTU-Qy diet $+30 \mathrm{mg} / \mathrm{kg}$ of $M$. sarasinorum extract (EM30)

Group VIII: $\quad$ PTU-Qy diet $+60 \mathrm{mg} / \mathrm{kg}$ of $M$. sarasinorum extract (EM60)

Group IX: $\quad$ PTU-Qy diet $+120 \mathrm{mg} / \mathrm{kg}$ of $M$. sarasinorum extract (EM120)

Group X: $\quad$ PTU-Qy diet $+30 \mathrm{mg} / \mathrm{kg}$ of Xestospongia sp. extract (EX30)

Group XI: $\quad$ PTU-QY diet $+60 \mathrm{mg} / \mathrm{kg}$ of Xestospongia $\mathrm{sp}$. extract (EX60)

Group XII: $\quad$ PTU-QY diet $+120 \mathrm{mg} / \mathrm{kg}$ of Xestospongia $\mathrm{sp}$. extract (EX120)

The designated groups of hyperlipidemic animals were treated orally with sponge extracts and simvastatin. Extracts and simvastatin $(0.18 \mathrm{mg} / \mathrm{ml})$ were diluted homogenously in $0.5 \% \mathrm{Na}-$
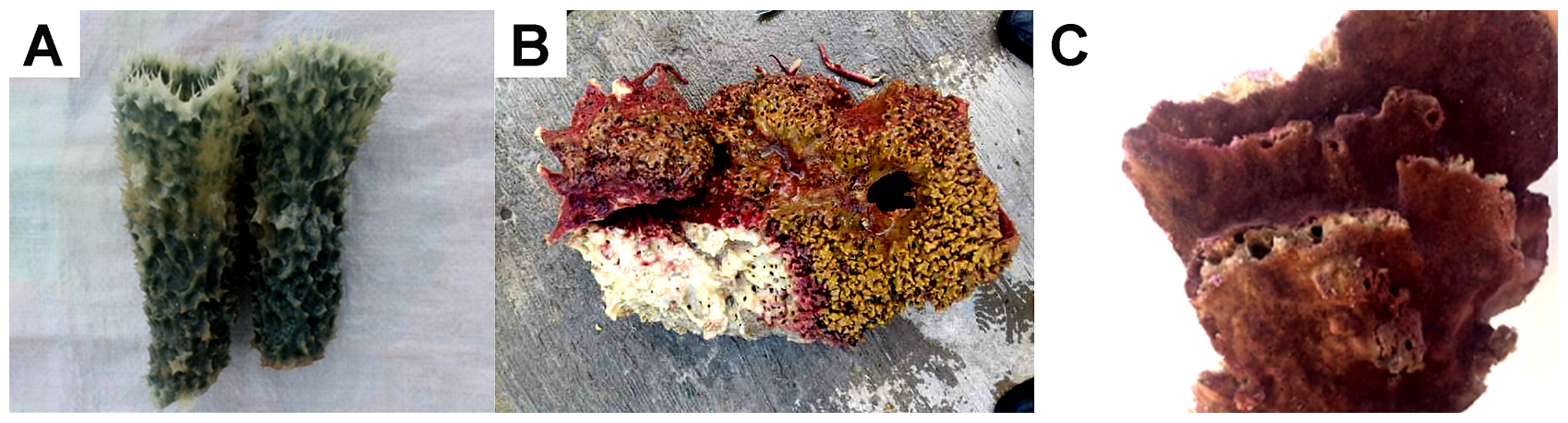

Figure 1. (A) Callyspongia sp.; (B) M. sarasinorum; (C) Xestospongia sp. 
CMC as the vehicle. After 1 week of treatment, blood was collected intracardially and transferred into Ethylenediaminetetraacetic acid (EDTA) tubes. Blood samples were let to stand for 1 hour at room temperature. Samples of blood-EDTA were then centrifuged at $3000 \mathrm{rpm}$ for 10 minutes and serum was separated for further biochemical analyses.

\section{Measurement of serum lipid profile}

Level of total cholesterol (TC), total triglycerides (TG), and high-density lipoproteins (HDL) in serum were spectrophotometrically measured using assay kits (Rajawali Nusindo, Catalog No. 1096778, Jakarta, Indonesia). The verylow-density lipoproteins (VLDL) were calculated as VLDL = [TG/5]. The serum level of low-density lipoproteins (LDL) was calculated using Friedewald's formula as $\mathrm{LDL}=\mathrm{TC}-(\mathrm{TG} / 5+$ HDL) (Friedewald et al., 1972).

\section{Atherogenic risk index, percentage protection, and atherogenic indices}

Atherogenic Index (AI) was calculated as AI $=[(\mathrm{TC}-$ HDL)/HDL]. Meanwhile, percentage protection of marine sponges extracts treated hyperlipidemic rats toward atherogenicity was calculated as $\%$ protection $=[($ AIPTU-QY diet group-AItreated group)/AIPTU-QY diet group] $\mathrm{x} 100$. Atherogenic indices that are Atherogenic Index Plasma (AIP) was calculated as AIP $=\log$ [TG/HDL-C], Castelli's Risk Index-I (CRI-I) was calculated as CRI-I $=[$ TC/HDL-C], and Castelli's Risk Index-II (CRI-II) was calculated as CRI-II = [LDL/HDL] (Chikezie et al., 2018; Dianita et al., 2016; Dobiášová et al., 2001).

\section{Chemical screening}

The extracts of Callyspongia sp., M. sarasinorum, and Xestospongia sp. were chemically screened to detect the occurrence of alkaloids, flavonoids, tannins, triterpenoids and steroids, and saponins. These types of compounds were screened by using the Dragendorf reagent, magnesium-chloric acid reagent, ferric chloride reagent, Liebermann-Burchard reagent, and foam test, respectively (Harborne, 1973).

\section{Statistical analysis}

Results were statistically analyzed using SPSS Statistics 17.0 (IBM Inc., USA). The comparison of data among groups was carried out using the One-way ANOVA, followed by Tukey's Test. The values of $p<0.05$ were considered statistically significant. Pearson's correlation was analyzed using the GraphPad Prism 5 (Graphpad Software, Inc., La Jola, USA). Data were presented as mean \pm standard deviation (SD).

\section{RESULTS AND DISCUSSION}

Cholesterol-rich dietary intake has been closely linked with the development of hypercholesterolemia in humans and animals. The imbalance of circulating cholesterol influx and efflux through the liver and cholesterol esterification has been a feature of lipid metabolism disturbances. Excessive cholesterol and fats in the plasma will accumulate the formation of macrophage foam cells which then deposited in the arterial walls, leading to an early stage of vascular atherosclerotic lesions (Douglas and Channon, 2014; Yu et al., 2013). The role of hypercholesterolemia in triggering atherosclerosis, along with other risk factors, such as diabetes, hypertension, smoking, male gender, and inflammatory conditions has been recognized and received a particular concern among clinicians and health care professionals. The accumulation of atherogenic conditions is associated with evidence of cardiovascular diseases and chronic kidney diseases (Falk, 2006).

Indications of hypercholesterolemia are characterized by increased levels of cholesterol and triglycerides in plasma as well as a high ratio of LDL to HDL. In this study, hypercholestemic condition made in rats as an animal model was developed by feeding the rats with PTU and quail yolk. The use of PTU in lowering hyperthyroidism has been associated with increased cholesterol levels (Santillo et al., 1999). Hence, PTU induction in rats resulted in a hypothyroid hypercholesterolemia status. In addition, feeding rats with quail yolk has been reported to increase the cholesterol level due to its lipid nutritional compositions (Tungsaringkarn et al., 2013). Our study showed that induction of hyperlipidemic condition in rats for 3 weeks with PTU and quail yolk was successfully developed, indicated by significant elevation of cholesterol $(56.8 \%)$, triglycerides (77.9\%), and LDL (86.3\%) productions as compared to the normal control group (Fig. 2). On the contrary, the HDL level in these rats was significantly reduced about $62.9 \%$, which suggested as a result of exogenous cholesterol and LDL up-take as well as the inhibition of cholesterol synthesis related to HDL origins (Deprés et al., 2000). The comparison of lipid profile in rats serum between the normal control group and hyperlipidemic groups after induction with PTUquail yolk diet was significantly different $(p<0.05)$, indicating an event of atherogenic condition. The development of atherogenicity may be due to the reduction of HDL level (Dianita et al., 2016). The diet of PTU-quail yolk increased the risk of atherogenicity in rats, showing by significant elevations of AI, AIP, CRI-I, and CRI-II values by $94.4 \%, 144.2 \%, 85.1 \%$, and $95.3 \%$, respectively (Table 1).

In this study, treatment of hyperlipidemic rats with ethanol extracts of Callyspongia sp., M. sarasinorum, and Xestospongia sp. found to reduce levels of TC and TG. Significant reduction of cholesterols level was showed by Callyspongia sp. extract at $120 \mathrm{mg} / \mathrm{kg}$ (EC120 group), decreasing by $40.2 \%$. This was followed by EM60, simvastatin, EM120, EX60, and EX120 groups with percentage decrements of $28.8 \%, 28.3 \%, 25.1 \%$, $22.6 \%$, and $20.2 \%$, respectively. The reduction of cholesterol in the EC120 group found to be lower than simvastatin group $(p>0.05)$, indicating a potent TC-lowering activity. Moreover, a significant reduction of triglycerides level was exhibited by EM60 and EM120 groups with percentage decrements of $42.5 \%$ and $36.9 \%$, respectively, and surprisingly lower than simvastatin (21.5\%). In addition, EC120 and EX60 groups did reduce the triglycerides level by $28.4 \%$ and $27.9 \%$, respectively. Treatment of hyperlipidemic rats with the extracts of marine sponges also reduced their LDLs level. Significant decreased LDLs level was shown by hyperlipidemic rats given with Callyspongia sp. at 120 $\mathrm{mg} / \mathrm{kg}$ (EC120 group), having a lipoprotein reduction by $153.5 \%$. This LDL-lowering activity was comparable to the simvastatin group (147.8\% reduction). On the other hand, EM60 and EX120 groups exhibited a similar reduction in serum LDL with percentages reduction of $79 \%$ and $60 \%$, respectively. Furthermore, significant increase of serum HDL level in hyperlipidemic rats with extracts of marine sponges was observed in groups treated with Xestospongia sp. extract at $60 \mathrm{mg} / \mathrm{kg}$ (EX60 group) and Callyspongia sp. extract at $120 \mathrm{mg} / \mathrm{kg}$ (EC120 group) in which the HDL levels increased 

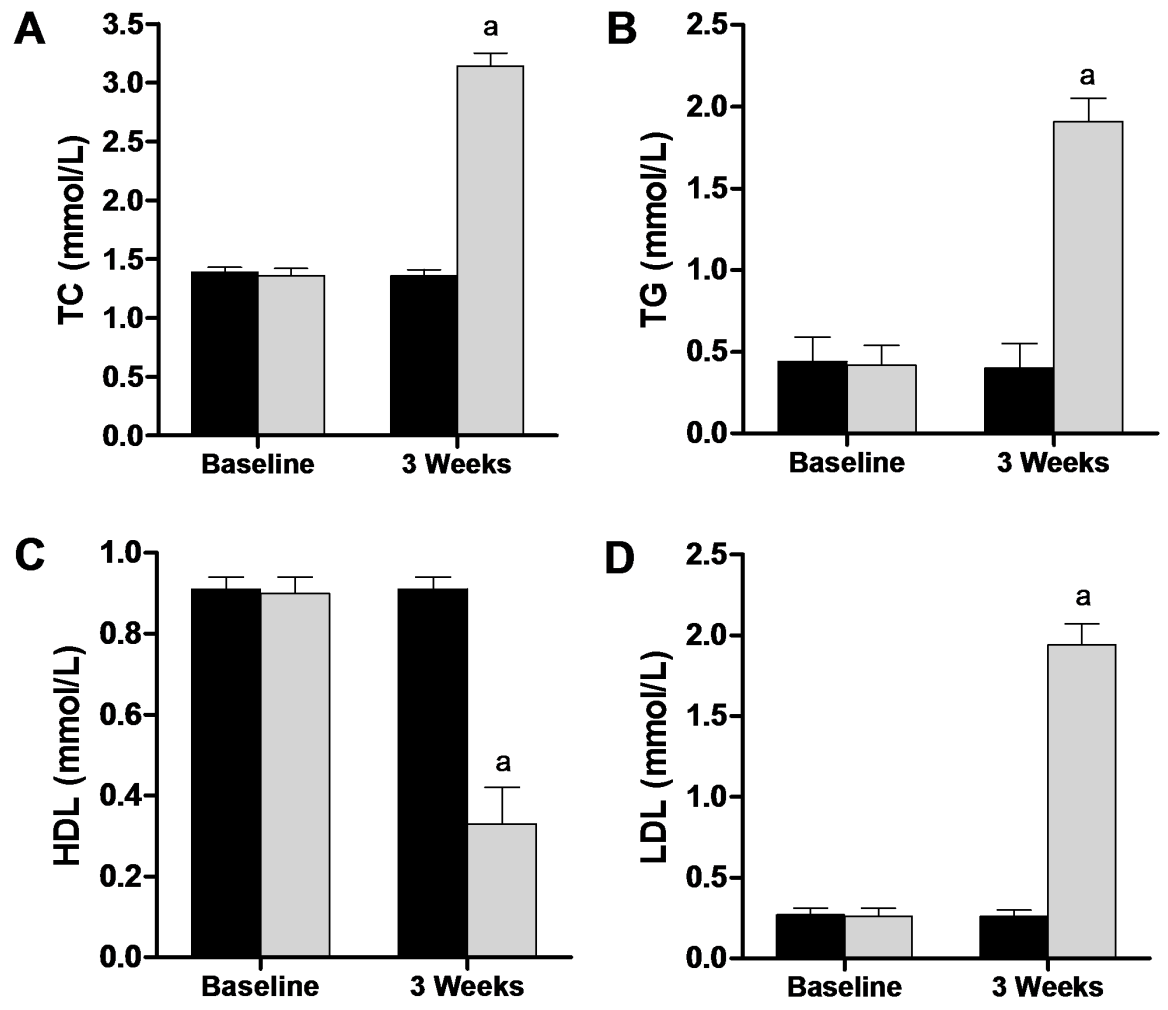

Normal control group

\section{PTU-Qy diet group}

Figure 2. The increased levels of cholesterol (A), triglycerides (B), and LDL (D) and the decrement of HDL level (C) in the hypercholesterolemic rats group induced by PTU-Qy diet. Data are presented in mean \pm SD

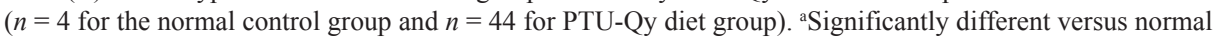
control group $(p<0.05)$.

Table 1. Elevation of atherogenicity risk of PTU-Qy diet-induced rats.

\begin{tabular}{llcccc}
\hline Group & Duration & AI & AIP & CRI-I & CRI-II \\
\hline Normal & Baseline & $0.52 \pm 0.08$ & $-0.33 \pm 0.15$ & $1.52 \pm 0.08$ & $0.29 \pm 0.05$ \\
& 3 weeks & $0.50 \pm 0.09$ & $-0.38 \pm 0.15$ & $1.50 \pm 0.09$ & $0.29 \pm 0.05$ \\
\multirow{2}{*}{ PTU-Qy } & Baseline & $0.51 \pm 0.09$ & $-0.34 \pm 0.12$ & $1.51 \pm 0.09$ & $0.30 \pm 0.05$ \\
& 3 weeks & $9.18 \pm 2.89^{\mathrm{a}}$ & $0.77 \pm 0.13^{\mathrm{a}}$ & $10.18 \pm 2.89^{\mathrm{a}}$ & $6.33 \pm 2.04^{\mathrm{a}}$ \\
\hline
\end{tabular}

Data are presented in mean $\pm \mathrm{SD}$ ( $n=4$ for the normal control group and $n=44$ for PTU-Qy diet group). ${ }^{\text {a }}$ Significantly different versus normal control group $(p<0.05)$.

by $62.5 \%$ and $58.0 \%$, respectively, comparable to simvastatin (61.6\%). The rising of HDL level also observed EM60 and EX120 groups, having their serum HDL levels increased by $54.1 \%$ and $54.8 \%$, respectively. Surprisingly, the HDL levels in EM60, EC120, and EX60 groups were restored significantly, comparable to the normal control and simvastatin groups $(p>0.05)$. These results are listed in Table 2 and illustrated in Figure 3.

Atherogenic indices are one of the important parameters that can be used to indicate the occurrence of atherosclerosis event (Chikezie et al., 2018; Dobiášová et al., 2001). Our results showed that treatments with extracts of marine sponges decreased the atherogenic index (AI) and atherogenic indices levels (AIP, CRI-I, and CRI-II) in hyperlipidemic rats (Table 3). Simvastatin, EC120, EM60, EM120, EX60, and EX120 groups lowered the AI, CRI-I, and CRI-II levels comparable to the normal control group ( $p>$ $0.05)$, and their levels were significantly different as compared to PTU-Qy diet group $(p<0.05)$. The lowering AIP levels of simvastatin and all sponges extracts were significantly different from normal control and PTU-Qy diet groups $(p<0.05)$. Indeed, AIP levels of EC120, EM60, EM120, EX60, and EX120 were comparable to the simvastatin group. It was consistent with AI, AIP, CRI-I, and CR-II levels that extracts of Callyspongia sp. (120 $\mathrm{mg} / \mathrm{kg}$ ), M. sarasinorum (60 and $120 \mathrm{mg} / \mathrm{kg}$ ), and Xestospongia sp. (60 and $120 \mathrm{mg} / \mathrm{kg}$ ) exhibited protection against atherogenicity in hyperlipidemic rats with percentages protection in the range of $70.6 \%-81.6 \%$ (Table 4). Pearson's correlation analysis revealed a significant positive correlation of AIP versus LDL level of all groups $(r=0.9225)$. Meanwhile, linear regression analysis of AIP 
Table 2. Level of cholesterol, triglycerides, HDL, and LDL of the normal control group and hypercholesterolemic rats before and after treatment with Callyspongia sp., M. sarasinorum, and Xestospongia sp. extracts.

\begin{tabular}{|c|c|c|c|c|c|c|c|c|}
\hline \multirow{2}{*}{ Group } & \multicolumn{2}{|c|}{ Cholesterol level } & \multicolumn{2}{|c|}{ Triglycerides level } & \multicolumn{2}{|c|}{ HDL level } & \multicolumn{2}{|c|}{ LDL level } \\
\hline & 3 weeks & 4 weeks & 3 weeks & 4 weeks & 3 weeks & 4 weeks & 3 weeks & 4 weeks \\
\hline Normal & $1.36 \pm 0.05^{\mathrm{a}, \mathrm{c}}$ & $1.36 \pm 0.05^{\mathrm{a}, \mathrm{c}}$ & $0.40 \pm 0.15^{\mathrm{a}, \mathrm{c}}$ & $0.44 \pm 0.12^{\mathrm{a}, \mathrm{c}}$ & $0.91 \pm 0.03^{\mathrm{a}, \mathrm{c}}$ & $0.85 \pm 0.07^{\mathrm{a}}$ & $0.26 \pm 0.04^{\mathrm{a}, \mathrm{c}}$ & $0.31 \pm 0.06^{\mathrm{a}, \mathrm{c}}$ \\
\hline PTU-Qy & $3.15 \pm 0.12^{\mathrm{b}}$ & $3.21 \pm 0.13^{\mathrm{b}, \mathrm{c}}$ & $1.92 \pm 0.16^{\mathrm{b}}$ & $1.93 \pm 0.14^{\mathrm{b}, \mathrm{c}}$ & $0.31 \pm 0.07^{\mathrm{b}}$ & $0.31 \pm 0.09^{\mathrm{b}, \mathrm{c}}$ & $1.97 \pm 0.10^{\mathrm{b}}$ & $2.02 \pm 0.11^{\mathrm{b}, \mathrm{c}}$ \\
\hline Simvastatin & $3.17 \pm 0.10^{\mathrm{a}}$ & $2.47 \pm 0.17^{\mathrm{a}, \mathrm{b}}$ & $1.93 \pm 0.15^{\mathrm{b}}$ & $1.58 \pm 0.13^{\mathrm{a}, \mathrm{b}}$ & $0.37 \pm 0.15^{\mathrm{b}}$ & $0.97 \pm 0.22^{\mathrm{a}}$ & $1.91 \pm 0.11^{\mathrm{b}}$ & $0.77 \pm 0.17^{\mathrm{a}, \mathrm{b}}$ \\
\hline EC30 & $3.05 \pm 0.07^{\mathrm{a}}$ & $2.90 \pm 0.11^{\mathrm{a}, \mathrm{b}, \mathrm{c}}$ & $1.91 \pm 0.08^{\mathrm{b}}$ & $1.82 \pm 0.10^{\mathrm{b}, \mathrm{c}}$ & $0.34 \pm 0.06^{\mathrm{b}}$ & $0.46 \pm 0.07^{\mathrm{b}, \mathrm{c}}$ & $1.84 \pm 0.04^{\mathrm{b}}$ & $1.60 \pm 0.07^{\mathrm{a}, \mathrm{b}, \mathrm{c}}$ \\
\hline EC60 & $3.11 \pm 0.04^{\mathrm{a}}$ & $2.77 \pm 0.10^{\mathrm{a}, \mathrm{b}, \mathrm{c}}$ & $1.92 \pm 0.16^{\mathrm{b}}$ & $1.73 \pm 0.13^{\mathrm{b}}$ & $0.35 \pm 0.06^{\mathrm{b}}$ & $0.61 \pm 0.09^{\mathrm{a}, \mathrm{b}, \mathrm{c}}$ & $1.87 \pm 0.05^{\mathrm{b}}$ & $1.38 \pm 0.18^{\mathrm{a}, \mathrm{b}, \mathrm{c}}$ \\
\hline $\mathrm{EC} 120$ & $3.09 \pm 0.12^{\mathrm{a}}$ & $2.20 \pm 0.03^{\mathrm{a}, \mathrm{b}, \mathrm{c}}$ & $1.96 \pm 0.08^{\mathrm{b}}$ & $1.53 \pm 0.05^{\mathrm{a}, \mathrm{b}}$ & $0.32 \pm 0.07^{\mathrm{b}}$ & $0.77 \pm 0.08^{\mathrm{a}}$ & $1.87 \pm 0.12^{\mathrm{b}}$ & $0.74 \pm 0.05^{\mathrm{a}, \mathrm{b}}$ \\
\hline EM30 & $3.03 \pm 0.14^{\mathrm{a}}$ & $2.72 \pm 0.21^{\mathrm{a}, \mathrm{b}, \mathrm{c}}$ & $1.89 \pm 0.13^{\mathrm{b}}$ & $1.76 \pm 0.14^{\mathrm{b}}$ & $0.33 \pm 0.06^{\mathrm{b}}$ & $0.51 \pm 0.13^{\mathrm{b}, \mathrm{c}}$ & $1.83 \pm 0.14^{\mathrm{b}}$ & $1.41 \pm 0.13^{\mathrm{a}, \mathrm{b}, \mathrm{c}}$ \\
\hline EM60 & $3.17 \pm 0.07^{\mathrm{a}}$ & $2.46 \pm 0.08^{\mathrm{a}, \mathrm{b}}$ & $1.94 \pm 0.12^{\mathrm{b}}$ & $1.36 \pm 0.10^{\mathrm{a}, \mathrm{b}}$ & $0.35 \pm 0.06^{\mathrm{b}}$ & $0.76 \pm 0.06^{\mathrm{a}}$ & $1.94 \pm 0.09^{\mathrm{b}}$ & $1.08 \pm 0.06^{\mathrm{a}, \mathrm{b}, \mathrm{c}}$ \\
\hline EM120 & $3.19 \pm 0.10^{\mathrm{a}}$ & $2.55 \pm 0.03^{\mathrm{a}, \mathrm{b}}$ & $1.94 \pm 0.07^{\mathrm{b}}$ & $1.42 \pm 0.05^{\mathrm{a}, \mathrm{b}}$ & $0.34 \pm 0.07^{\mathrm{b}}$ & $0.69 \pm 0.03^{\mathrm{a}, \mathrm{c}}$ & $1.96 \pm 0.11^{\mathrm{b}}$ & $1.21 \pm 0.04^{\mathrm{a}, \mathrm{b}, \mathrm{c}}$ \\
\hline EX30 & $3.19 \pm 0.08^{\mathrm{a}}$ & $3.07 \pm 0.09^{\mathrm{b}, \mathrm{c}}$ & $1.66 \pm 0.17^{\mathrm{b}}$ & $1.55 \pm 0.11^{\mathrm{a}, \mathrm{b}}$ & $0.31 \pm 0.10^{\mathrm{b}}$ & $0.43 \pm 0.11^{\mathrm{b}, \mathrm{c}}$ & $2.12 \pm 0.17^{\mathrm{b}}$ & $1.93 \pm 0.17^{\mathrm{b}, \mathrm{c}}$ \\
\hline EX60 & $3.12 \pm 0.20^{\mathrm{a}}$ & $2.55 \pm 0.13^{\mathrm{a}, \mathrm{b}}$ & $1.88 \pm 0.07^{\mathrm{b}}$ & $1.47 \pm 0.05^{\mathrm{a}, \mathrm{b}}$ & $0.29 \pm 0.12^{\mathrm{b}}$ & $0.78 \pm 0.06^{\mathrm{a}}$ & $1.97 \pm 0.13^{\mathrm{b}}$ & $1.10 \pm 0.07^{\mathrm{a}, \mathrm{b}, \mathrm{c}}$ \\
\hline EX120 & $3.19 \pm 0.07^{\mathrm{a}}$ & $2.66 \pm 0.10^{\mathrm{a}, \mathrm{b}}$ & $1.94 \pm 0.07^{\mathrm{b}}$ & $1.67 \pm 0.05^{\mathrm{a}, \mathrm{b}}$ & $0.31 \pm 0.10^{\mathrm{b}}$ & $0.68 \pm 0.12^{\mathrm{a}, \mathrm{c}}$ & $2.00 \pm 0.16^{\mathrm{b}}$ & $1.22 \pm 0.15^{\mathrm{a}, \mathrm{b}, \mathrm{c}}$ \\
\hline
\end{tabular}

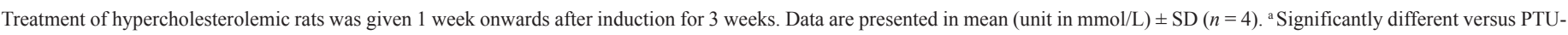
Qy control group $(p<0.05)$; ${ }^{\text {b }}$ significantly different vs. normal control group $(p<0.05)$; $^{\text {c }}$ significantly different versus $\operatorname{simvastatin}$ group $(p<0.05)$.

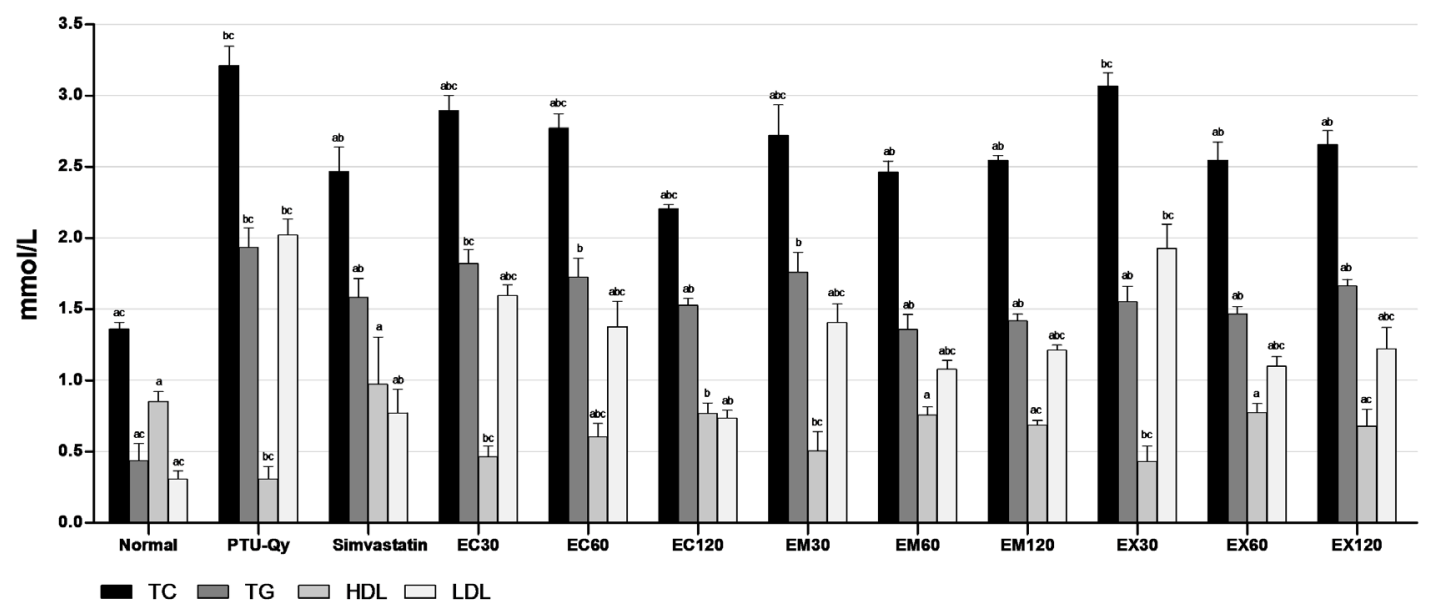

Figure 3. Effects of ethanol extracts of Callyspongia sp., M. sarasinorum, and Xestospongia sp. on serum lipid profile of normal and hypercholesterolemic rats. Data is presented as mean $\pm \mathrm{SD}(n=4)$. a Significantly different vs. PTU-Qy control group $(p$

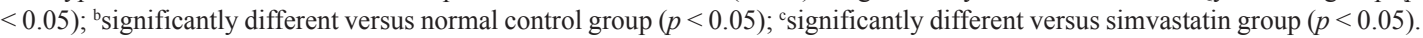

versus LDL level showed a relatively fitted curve $\left(r^{2}=0.8510\right)$ (Fig. 4). The reduction of these atherogenic indices by ethanol extracts of marine sponges indicated an alleviating activity of atherosclerosis. High doses of extracts also showed protections against the atherogenic condition in hyperlipidemic rats.

Biological activities of marine species on hypercholesterolemia and hyperlipidemia have been reported in some studies. Extracts and polysaccharides extracted from marine algae (seaweeds) have proven to exhibit antihyperlipidemic activity and a restoring activity on liver damage (Ren et al., 1994; Wang et al., 2014). In addition, compounds isolated from sponges-associated fungi showed lipid-lowering activity assayed using in vitro and in vivo models (Blunt and Munro, 2008; Li et al., 2014). Our findings showed that extracts of Callyspongia sp. (EC), M. sarasinorum (EM), and Xestospongia sp. (EX) have a potent antihyperlipidemic activity. The role of simvastatin in reducing cholesterol level has been proven due to the inhibition of 3-hydroxy-3-methylglutaryl coenzyme A reductase (HMGCR). HMGCR is a rate-limiting enzyme that produces mevalonate as a precursor for cholesterol biosynthesis in the liver. Studies also showed that this drug has properties on anti-atherosclerosis, antioxidant, anti-inflammatory, vasodilatation, and antioxidant activities (Sparrow et al., 2001; Stancu and Sima, 2001; Zhou and Liao, 2009). Our study suggests that compounds present in ethanol extracts of Callyspongia sp., M. sarasinorum, and Xestospongia sp. may exhibit antihyperlipidemic property similar to simvastatin and possibly other statin drugs. Statins therapy for hypercholesterolemia and hyperlipidemia may be effective when LDL and TG levels reduced and modest HDL level increased (Trentman et al., 2016). However, the roles of compounds in extracts for treating hyperlipidemic condition may also vary; at least there are several types of marketed drugs used for this purpose, including inhibitors of HMGCR in the liver (endogenous production), inhibitors of intestinal cholesterol 
Table 3. Atherogenic indices of normal and hypercholesterolemic rats after treatment with Callyspongia sp., M. sarasinorum, and Xestospongia sp. extracts.

\begin{tabular}{lcccc}
\hline Group & AI & AIP & CRI-I & CRI-II \\
\hline Normal & $0.61 \pm 0.14^{\mathrm{a}}$ & $-0.30 \pm 0.14^{\mathrm{a}, \mathrm{c}}$ & $1.61 \pm 0.14^{\mathrm{a}}$ & $0.36 \pm 0.10^{\mathrm{a}}$ \\
PTU-Qy & $10.31 \pm 3.17^{\mathrm{b}, \mathrm{c}}$ & $0.82 \pm 0.12^{\mathrm{b}, \mathrm{c}}$ & $11.31 \pm 3.17^{\mathrm{b}, \mathrm{c}}$ & $7.20 \pm 2.38^{\mathrm{b}, \mathrm{c}}$ \\
Simvastatin & $1.63 \pm 0.49^{\mathrm{a}}$ & $0.22 \pm 0.11^{\mathrm{a}, \mathrm{b}}$ & $2.63 \pm 0.49^{\mathrm{a}}$ & $0.85 \pm 0.33^{\mathrm{a}}$ \\
EC30 & $5.34 \pm 0.77^{\mathrm{a}, \mathrm{b}, \mathrm{c}}$ & $0.60 \pm 0.06^{\mathrm{a}, \mathrm{b}, \mathrm{c}}$ & $6.34 \pm 0.88^{\mathrm{a}, \mathrm{b}, \mathrm{c}}$ & $3.52 \pm 0.65^{\mathrm{a}, \mathrm{b}, \mathrm{c}}$ \\
EC60 & $3.67 \pm 0.67^{\mathrm{a}, \mathrm{b}}$ & $0.46 \pm 0.08^{\mathrm{a}, \mathrm{b}, \mathrm{c}}$ & $4.67 \pm 0.77^{\mathrm{a}, \mathrm{b}}$ & $2.34 \pm 0.58^{\mathrm{a}}$ \\
EC120 & $1.90 \pm 0.23^{\mathrm{a}}$ & $0.30 \pm 0.05^{\mathrm{a}, \mathrm{b}}$ & $2.90 \pm 0.27^{\mathrm{a}}$ & $0.97 \pm 0.16^{\mathrm{a}}$ \\
EM30 & $4.59 \pm 0.95^{\mathrm{a}, \mathrm{b}}$ & $0.55 \pm 0.15^{\mathrm{a}, \mathrm{b}, \mathrm{c}}$ & $5.59 \pm 1.09^{\mathrm{a}, \mathrm{b}}$ & $2.88 \pm 0.53^{\mathrm{a}, \mathrm{b}}$ \\
EM60 & $2.28 \pm 0.27^{\mathrm{a}}$ & $0.26 \pm 0.06^{\mathrm{a}, \mathrm{b}}$ & $3.28 \pm 0.31^{\mathrm{a}}$ & $1.44 \pm 0.20^{\mathrm{a}}$ \\
EM120 & $2.72 \pm 0.13^{\mathrm{a}}$ & $0.32 \pm 0.01^{\mathrm{a}, \mathrm{b}}$ & $3.72 \pm 0.15^{\mathrm{a}}$ & $1.77 \pm 0.13^{\mathrm{a}}$ \\
EX30 & $6.47 \pm 1.83^{\mathrm{a}, \mathrm{b}, \mathrm{c}}$ & $0.56 \pm 0.12^{\mathrm{a}, \mathrm{b}, \mathrm{c}}$ & $7.47 \pm 2.12^{\mathrm{a}, \mathrm{b}, \mathrm{c}}$ & $4.75 \pm 1.68^{\mathrm{a}, \mathrm{b}, \mathrm{c}}$ \\
EX60 & $2.29 \pm 0.11^{\mathrm{a}}$ & $0.28 \pm 0.04^{\mathrm{a}, \mathrm{b}}$ & $3.29 \pm 0.13^{\mathrm{a}}$ & $1.42 \pm 0.06^{\mathrm{a}}$ \\
EX120 & $3.03 \pm 0.74^{\mathrm{a}}$ & $0.40 \pm 0.10^{\mathrm{a}, \mathrm{b}}$ & $4.03 \pm 0.85^{\mathrm{a}}$ & $1.88 \pm 0.58^{\mathrm{a}}$ \\
\hline
\end{tabular}

Data is presented as mean $\pm \mathrm{SD}(n=4) .{ }^{\text {a }}$ Significantly different vs. PTU-Qy control group $(p<0.05) ;{ }^{\mathrm{b}}$ significantly different versus normal control group $(p<0.05) ;{ }^{\mathrm{c}}$ significantly different versus simvastatin group $(p<0.05)$.

Table 4. Percentage protection of Callyspongia sp., M. sarasinorum, and Xestospongia sp. extracts and simvastatin in hypercholesterolemic rats.

\begin{tabular}{lc}
\hline Group & \% Protection \\
\hline Simvastatin & 84.2 \\
EC30 & 48.2 \\
EC60 & 64.4 \\
EC120 & 81.6 \\
EM30 & 55.5 \\
EM60 & 77.9 \\
EM120 & 73.6 \\
EX30 & 46.5 \\
EX60 & 77.8 \\
EX120 & 70.6 \\
\hline
\end{tabular}

absorptions, and inhibitors of bile acids re-uptake to the liver (Mahamuni et al., 2012). Chemical screening showed the occurrence of alkaloids, flavonoids, steroids, triterpenoids, and saponins in all sponge extracts (Table 5). Moreover, tannins were only detected in the extract of $M$. sarasinorum. The prospective of these natural products in cholesterol-lowering activity is still being investigated and some studies have shown positive results. Alkaloids have been reported to exhibit cholesterollowering effects by improving stability of LDL receptor mRNA, increasing uptake, and conversion of cholesterol into bile acids, down-regulating cholesterol biosynthesis at mRNA level of HMGCR, and improving cholesterol transport. The combination of alkaloids is suggested to provide better cholesterol synthesis inhibition and to promote cholesterol catabolism and excretion (Kou et al., 2016; Pirillo and Capatano, 2015; Zhang et al., 2018b). Studies have shown that flavonoids inhibited the HMGCR activity. In addition, the antioxidant activities by flavonoids prevent lipid peroxidation and scavenge free radicals. Accumulation of excessive LDL has led to the formation of modified oxidized-LDL (oxLDL), which plays a key role during

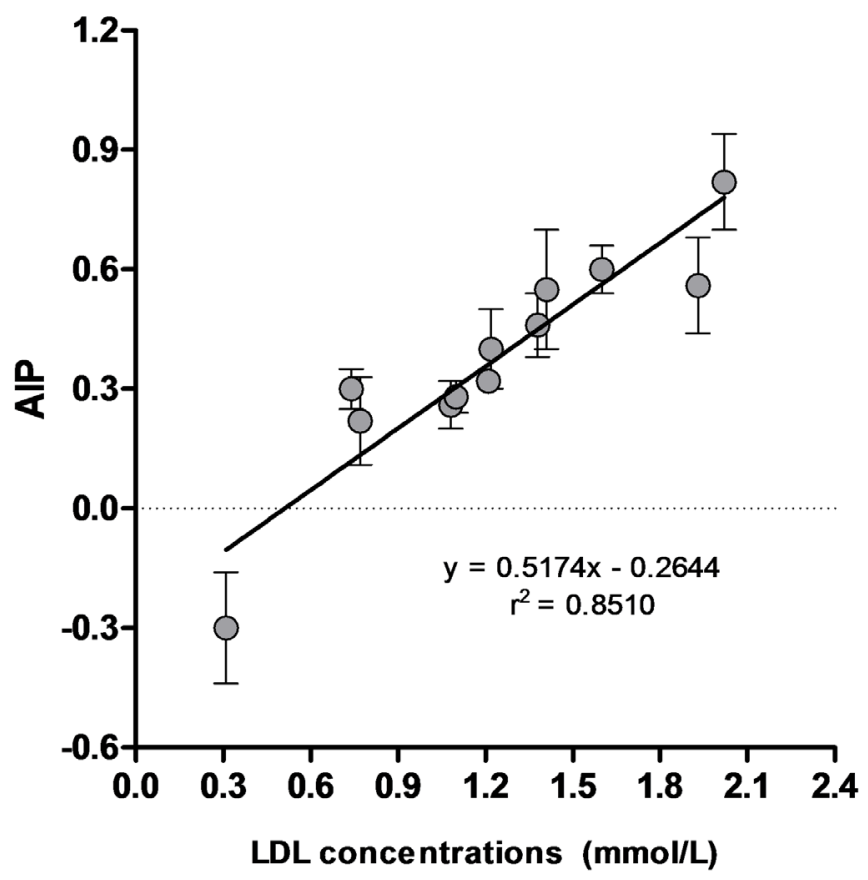

Figure 4. Linear regression curve of AIP versus LDL concentrations of all experimental groups

atherosclerosis. Flavonoids also block the oxLDL uptake by macrophages, preventing the formation of foam cells (Kumar and Pandey, 2013; Salvamani et al., 2014). The lipid-lowering activity and anti-atherosclerosis of triterpenoids have reported on inhibition of LDL-induced lipid deposition aggregation in macrophages. The activity is due to down regulated of LDL receptor-related protein 1 (Zheng et al., 2015). Triterpenoids have also shown inhibitory activity against in vitro HMGCR enzyme (Zhang et al., 2018b). Steroids from plants and marine species have shown their lipid-lowering effect by binding activity to micelles, resulted in competition with cholesterol during intestinal absorption and transport. They also more hydrolyzed compared to cholesterol. Hence, their presence in intestine reduced the cholesterol solubility to form micelles, resulting in less cholesterol absorption and more cholesterol fecal excretion (Gupta et al., 2011; Kritchevsky et al., 1999; Trautwein et al., 2003). Steroids and triterpenoids have also been reported as liver $\mathrm{X}$ receptors agonists which play a significant role in cholesterol homeostatis (Jayasuriya et al., 2005). Saponins (triterpenoidaland steroidal glycosides) have also been studied for their roles in cholesterol metabolism. Interaction between saponins and bile acids formed large micelles, thus interfere with the enterohepatic circulation of bile acids for intestinal absorption. As a result, the interaction then increased the fecal biliary excretion. The lipid-lowering activity of saponins is also due to their activity to modify LDL cholesterol levels (Francis et al., 2002; Malinow, 1984). Polymeric tannins reduced plasma LDL levels and increased the fecal excretion of lipids and cholesterol in rats. The binding interaction between tannins-rich fiber and bile acids is suggested for cholesterol-lowering activity in humans. The lipid-lowering activity of tannins has also been associated with their antioxidant activity which prevents lipid peroxidation and 
Table 5. Chemical screening of Callyspongia sp., M. sarasinorum, and Xestospongia sp. extracts.

\begin{tabular}{|c|c|c|c|c|c|c|}
\hline Sponge sample & Code & Alkaloids & Flavonoids & Tannins & Triterpenoids/steroids & Saponins \\
\hline Callyspongia sp. & $\mathrm{EC}$ & + & + & - & + & + \\
\hline M. sarasinorum & EM & + & + & + & + & + \\
\hline Xestospongia sp. & EX & + & + & - & + & + \\
\hline
\end{tabular}

scavenges free radicals (Gato et al., 2013; Smeriglio et al., 2017; Tebib et al., 1994). Our study suggested that the combination of these types of compounds in extracts of Callyspongia sp., $M$. sarasinorum, and Xestospongia sp. may work synergistically for exhibiting lipids-lowering activity in the treated hyperlipidemic rats. The antihyperlipidemic activity of these sponges is firstly reported from this study.

\section{CONCLUSION}

Ethanol extracts of marine sponges Callyspongia sp., M. sarasinorum, and Xestospongia sp. exhibited a lipid-lowering activity in hyperlipidemic rats. The extracts also showed protection against atherosclerosis. The activities might be resulted in the roles of alkaloids, flavonoids, steroids, triterpenoids, saponins, and tannins. Hence, ethanol extracts of these sponges could be used as sources of lead molecules in the development of natural lipid-lowering agents from marine species.

\section{ACKNOWLEDGMENT}

The authors would like to thank the Ministry of Research, Technology, and Higher Education of the Republic of Indonesia for a research grant scheme (Penelitian Dasar Unggulan Perguruan Tinggi 2018) for financial support.

\section{CONFLICT OF INTEREST} interest.

The authors declared that they have no conflict of

\section{REFERENCES}

Artanti N, Maryani F, Mulyani H, Dewi RT, Saraswati V, Murniasih T. Bioactivities screening of Indonesian marine bacteria isolated from sponges. Ann Bogor, 2016; 20:25-30.

Blunt, JW, Munro, MHG. Dictionary of marine natural products with CD-ROM. Chapman and Hall/CRC, Taylor and Francis, Boca Raton, FL, 2008.

Chikezie CM, Ojiako OA, Emejulu AA, Chikezie PC. Atherogenicity of diabetic rats administered single and combinatorial herbal extracts. Bull Fac Phar Cairo Univ, 2018; 56:169-74.

Cita YP, Suhermanto A, Radjasa OK, Sudharmono P. Antibacterial activity of marine bacteria isolated from sponge Xestospongia testudinaria from Sorong, Papua. Asian Pac J Trop Biomed, 2017; 7:450-4.

Clark MA, Finkel R, Rey JA, Whalen K. Lippincott illustrated reviews: pharmacology. 5th edition, Lippincott Williams \& Wilkins, Baltimore, MD, 2012.

Dahuri. Keanekaragaman hayati laut. PT Gramedia Pustaka Utama, Jakarta, Indonesia, 2003.

Deprés JP, Lemieux I, Dagenais GR, Bernard C, Lamarche B. HDL-cholesterol as a marker of coronary heart disease risk; the Québec cardiovascular study. Atherosclerosis, 2000; 153:263-72.

Dianita R, Jantan I, Jalil J, Amran AZ. Effects of Labisia pumila var alata extracts on the lipid profile, serum antioxidant status and abdominal aorta of high-cholesterol diet rats. Phytomed, 2016; 23:810-7.

Dobiášová M, Frohlich, J. The plasma parameter log (TG/ HDL-C) as an atherogenic index: correlation with lipoprotein particle size and esterification rate in apoB-lipoprotein-depleted plasma (FER(HDL)). Clin Biochem, 2001; 34:583-8.

Douglas G, Channon KM. The pathogenesis of atherosclerosis. Medicine, 2014; 42(9):480-4.

Falk E. Pathogenesis of atherosclerosis. J Am Coll Cardiol, 2006; 47:C7-12.

Francis G, Kerem Z, Makkar HPS, Becker K. The biological action of saponins in animal systems: a review. British J Nutr, 2002; 88:587-605.

Friedewald WT, Levy RI, Fredrickson DS. Estimation of the concentration of low-density lipoprotein cholesterol in plasma, without use of the preparative ultracentrifuge. Clin Chem, 1972; 18:499-502.

Gato N, Kadowaki A, Hashimoto N, Yokoyama S, Matsumoto K. Persimmon fruit tannin-rich fiber reduces cholesterol levels in humans. Ann Nutr Metab, 2013; 62:1-6.

Gupta AK, Savopoulos CG, Ahuja J, Hatzitolios AI. Role of phytosterols in lipid-lowering: current perspectives. QJ Med, 2011; 104:301-8.

Hariani N, Firdaus, Nafie NL, Permatasari NU, Sapar A. A preliminary study of sponge species from Kapoposang Island, Spermonde Archipelago and bioactivity test of their methanol extracts. Proceeding of the First International Conference on Science (ICOS)-1, pp 376-81, 2014.

Harborne JB. Phytochemical methods, a guide to modern techniques of plant analysis. Chapman and Hall, London, UK, 1973.

Ivanchina NV, Kicha AA, Stonik VA. Steroid glycosides from marine organisms. Steroids, 2011; 76:425-54.

Jayasuriya H, Herath KB, Ondeyka JG, Guan Z, Borris RP, Tiwari S, Jong W, Chavez F, Moss J, Stevenson DW, Beck HT, Slattery M, Zamora N, Schulman M, Ali A, Sharma N, MacNaul, K, Hayes N, Menke JG, Singh SB. Diterpenoid, steroid, and triterpenoid agonists of liver X receptors from diversified terrestrial plants and marine sources. J Nat Prod, $2005 ; 68: 1247-52$.

Kou S, Han B, Wang Y, Huang T, He K, Han Y, Zhou X, Ye X, Li $\mathrm{X}$. Synergetic cholesterol-lowering effects of main alkaloids from Rhizoma coptidis in HepG2 cells and hypercholesterolemia hamsters. Life Sci, 2016; 151:50-60.

Kritchevsky D, Tepper SA, Czarnecki SK, Kyle DJ. Effects of 4-methylsterols from algae and of $\beta$ sitosterol on cholesterol metabolism in rats. Nutr Res, 1999; 19:1649-54.

Kumar S, Pandey AK. Chemistry and biological activities of flavonoids: an overview. Sci World J, 2013; Article ID 162750.

Li Y, Wu C, Liu D, Proksch P, Guo P, Lin W. Chartarlactams A-P, phenylspirodrimanes from the sponge-associated fungus Stachybotrys chartarum with antihyperlipidemic activities. J Nat Prod 2014; 77:138-47.

Mahamuni SP, Khose RD, Menaa F, Badole SL. Therapeutic approaches to drug targets in hyperlipidemia. BioMed, 2012; 2:137-46.

Malinow MR. Saponins and cholesterol metabolism. Atherosclerosis, 1984; 50:117-9.

Menggelea FP, Posangi JP, Wowor MP, Bara R. Uji efek antibakteri jamur endosimbion spons laut Callyspongia sp. terhadap bakteri Pseudomonas aeruginosa dan Eschericia coli. Jurnal e-Biomedik, 2015; 3:376-80.

Pirillo A, Capatano AL. Berberine, a plant alkalod with lipidand glucose-lowering properties: from in vitro evidence to clinical studies. Atherosclerosis, 2015, 243:449-61.

Ren D, Noda H, Amano H, Nishino T, Nishizawa K. Study on antihypertensive and antihyperlipidemic effects of marine algae. Fish Sci, 1994; 60:83-8. 
Salvamani S, Gunasekaran B, Shaharuddin NA, Ahmad SA, Shukor MY. Antiartherosclerotic effects of plant flavonoids. BioMed Res Int, 2014; Article ID 480258.

Santillo M, Migliaro A, Mondola P, Laezza C, Damiano S, Stingo S, Fiorentino L, Andreozzi A, Vitale M, Bifulco M. Dietary and hypothyroid hypercholesterolemia induces hepatic apolipoprotein E expression in the rat: direct role of cholesterol. FEBS Lett, 1999; 463:83-6.

Smeriglio A, Barreca D, Bellocco E, Trombetta D. Proanthocyanidins and hydrosable tannins: occurrence, dietary intake and pharmacological effects. British J Pharmacol, 2017; 174:1244-62.

Sparrow CP, Burton CA, Hernandez M, Mundt S, Hassing H, Patel S, Rosa R, Hermanowski-Vosatka A, Wang PR, Zhang D, Peterson L, Detmers PA, Chao YS, Wright SD. Simvastatin has anti-inflammatory and antiatherosclerotic activities independent of plasma cholesterol lowering. Arterioscler Thromb Vasc Biol, 2001; 21:115-21.

Stancu C, Sima A. Statins: mechanism of action and effects. J Cell Mol Med, 2001; 5:378-87.

Tapilatu YH. Status of drug discovery research based on marine organisms from eastern Indonesia. Procedia Chem, 2015; 14:484-92.

Tebib K, Bitri L, Besançon P, Rouanet J-M. Polymeric grape seed tannins prevent plasma cholesterol changes in high-cholesterol-fed rats. Food Chem, 1994; 49:403-6.

Trautwein EA, Duchateau GSMJE, Lin Y, Mel'nikov SM, Molhuizen HOF, Ntanios FY. Proposed mechanisms of cholesterollowering action of plant sterols. Eur J Lipid Sci Technol, 2003; 105:171-85.

Trentman TL, Avey SG, Ramakrishna H. Current and emerging treatments for hypercholesterolemia: a focus on statins and proprotein convertase subtilisin/kexin type 9 inhibitors for perioperative clinicians. J Anaesthesiol Clin Pharmacol, 2016; 32:440-5.

Tunsaringkarn T, Tungjaroenchai W, Siriwong W. Nutrient benefits of quail (Coturnix coturnix japonica) eggs. Int J Sci Res Pub, 2013; $3: 1-8$.

Wang L, Wang X, Wu H, Liu R. Overview on biological activities and molecular characteristics of sulfated polysaccharides from marine green algae in recent years. Mar Drugs, 2014; 12:4984-5020.

World Health Organization (WHO). Cardiovascular diseases (CVDs), 2017. Available via https://www.who.int/news-room/fact-sheets/ detail/cardiovascular-diseases-(cvds) (Accessed 28 February 2019).
Yu X-H, Fu Y-C, Zhang D-W, Yin K, Tang C-K. Foam cells in atherosclerosis. Clin Chim Acta, 2013; 424:245-52.

Zhang J, Ma K, Han J, Wang K, Chen H, Bao L, Liu L, Xiong W, Zhang Y, Huang Y, Liu H. Eight new triterpenoids with inhibitory activity against HMG-CoA reductase from the medical mushroom Ganoderma leucocontextum collected in Tibetan plateau. Fitoterapia, 2018a; 130:79-88.

Zhang X, Jin Y, Wu Y, Zhang C, Jin D, Zheng Q, Li Y. Antihyperglycemic and anti-hyperlipidemia effects of the alkaloid-rich extract from barks of Litsea glutinosa in ob/ob mice. Sci Rep 2018b; 8: Article number 12646

Zheng J, Zhou H, Zhao Y, Lun Q, Liu B, Tu P. Triterpenoidenriched extract of Ilex kudingcha inhibits aggregated LDL-induced lipid deposition in macrophages by downregulating low density lipoprotein receptor-related protein 1 (LRP1). J Function Foods, 2015; 18:643-52.

Zhou Q, Liao JK. Statins and cardiovascular disease: from cholesterol lowering to pleiotropy. Curr Pharm Des, 2009; 15:467-78.

\section{How to cite this article:}

Wahyuni W, Fristiohady A, Malaka MH, Malik F, Yusuf MI, Leorita M, Sadarun B, Saleh A, Musnina WOS, Sabandar CW, Sahidin I. Effects of Indonesian marine sponges ethanol extracts on the lipid profile of hyperlipidemic rats. J Appl Pharm Sci, 2019; 9(10):001-008. 